\title{
Bacterial Communities in a Full-scale Combined A/O+BIOFOR System Treating Pharmaceutical Wastewater
}

\author{
Erming Ouyang ${ }^{1}$, Yao Lu ${ }^{1}$, Jiating Ouyang ${ }^{1}$, \\ Xiaojia Liu², Xiaohui Wang ${ }^{2 *}$ \\ ${ }^{1}$ School of Civil Engineering and Architecture, Nanchang University, Nanchang 330031, China \\ ${ }^{2}$ College of Chemical Engineering, Beijing University of Chemical Technology, Beijing 100029, China
}

Received: 7 March 2017

Accepted: 16 April 2017

\begin{abstract}
Mixed pharmaceutical wastewater contains high levels of chemical oxygen demand (COD) and high concentrations of toxic and harmful substances. A conventional wastewater treatment process cannot treat this wastewater sufficiently to meet discharge standards. Therefore, mixed pharmaceutical wastewater treatment is a serious challenge to wastewater management. In this study, a full-scale combined anaerobic/ oxic $(\mathrm{A} / \mathrm{O})$ and biological filtration oxygenated reactor $\left(\mathrm{BIOFOR}^{\circledR}\right)$ process was used to treat the mixed pharmaceutical wastewater. The objectives were to evaluate the removal efficiency of the combined $\mathrm{A} / \mathrm{O}+\mathrm{BIOFOR}$ process on mixed pharmaceutical wastewater and to examine the bacterial community structures in process. The results showed that the effluent concentration of $\mathrm{COD}, \mathrm{NH}_{4}{ }^{-} \mathrm{N}$, and SS could meet the Chinese mission standard of water pollutants for the pharmaceutical industry mixing/compounding and formulation category (GB21908-2008). MiSeq sequencing data showed that the two systems (A/O and BIOFOR) harbored different bacterial diversity and communities. In phylum level, candidatedivision-TM7 was the most predominant phylum in the A/O system, while Proteo bacteria was the most dominant phylum in the BIOFOR reactor. At the genus level, 126 genera were unique in A/O or BIOFOR reactors. The results of this study provided insights into the bacterial community structure and diversity in pharmaceutical wastewater treatment system and can provide reference for the treatment of mixed pharmaceutical wastewater.
\end{abstract}

Keywords: pharmaceutical wastewater, $\mathrm{A} / \mathrm{O}+\mathrm{BIOFOR}$ process, miseq sequencing, bacterial community

\section{Introduction}

Pharmaceutical wastewater is one of the most important sources of industrial wastewater, and it contains a large

*e-mail: 379979971@qq.com number of hazardous and toxic substances and has strong bacterial toxicity. Pharmaceutical wastewaters from the manufacturing of antibiotics could significantly impact the environment, as they could interrupt the biological treatment processes in sewage treatment plants because of the recalcitrant and toxic compounds [1-3], leading to the release of incompletely degraded pollutants into the environment. 
The anaerobic/oxic (A/O) process consists of sequential anaerobic and aerobic stages for biological phosphorus removal [4]. The A/O process has been widely used for sewage treatment in both urban and rural areas and is favored for its high efficiency and low energy consumption [5]. The biological filtration oxygenated reactor (BIOFOR) process has high biofilm concentration and strong retention capacity. This process uses a special aeration head that can effectively supply oxygen and is easy to operate and maintain. The distribution of fluid in BIOFOR is completely uniform. The novel combined $\mathrm{A} / \mathrm{O}+\mathrm{BIOFOR}$ process combines the advantages of the two technologies.

Examining the microbial community structures of this novel process is necessary for understanding the complex interactions occurring in the system and finding ways to improve the design and operation of the process [6-7]. Molecular biology techniques have been used to analyze microbial community structures in activated sludge since 1995 [8]. However, because of low throughput, the application of traditional molecular methods was limited [9]. In recent years, with the development of nextgeneration DNA sequencing techniques, high-throughput sequencing such as Illumina MiSeq sequencing has been introduced to improve the analysis of microbial diversity [10-11].

In this study, a full-scale $\mathrm{A} / \mathrm{O}+\mathrm{BIOFOR}$ process was used to treat mixed pharmaceutical wastewater. The objectives were to assess the treatment effect of the combined $\mathrm{A} / \mathrm{O}+\mathrm{BIOFOR}$ process on mixed pharmaceutical wastewater and to examine the bacterial community structures in the aeration tank of $\mathrm{A} / \mathrm{O}$ process and $\mathrm{BIOFOR}$ reactor.

\section{Materials and Methods}

\section{Raw Water}

The mixed pharmaceutical wastewater was obtained from a medical company located in Jiangxi, China $\left(115.532487^{\circ} \mathrm{E}, 28.048071^{\circ} \mathrm{N}\right)$. This company is mainly engaged in the development and production of various types of health care products and external disinfection products. The wastewater is mainly divided into two parts: production wastewater and domestic sewage in the factory. The production wastewater is mainly obtained from the steps of extracting, washing drugs, washing bottles, washing equipment, and washing workshop grounds. The domestic sewage mainly is generated by the production staff, office staff, and the canteen.

\section{Sample Collection}

In summer 2015 we collected activated sludge samples from the aeration pool of the $\mathrm{A} / \mathrm{O}$ process and the BIOFOR reactor once a day for three consecutive days to generate triplicates from a currently functioning sewage treatment facility. In total, six samples were collected, and each sample was dispensed into a $1.5 \mathrm{~mL}$ sterile Eppendorf tube and centrifuged at $14,000 \times \mathrm{g}$ for $10 \mathrm{~min}$. The supernatant was decanted, and the pellets were stored at $-20^{\circ} \mathrm{C}$ prior to analysis.

\section{DNA Extraction and PCR Amplification}

The pellets of the samples were washed three times by centrifuge using sterile high-purify water for 5 min at 15,000 g. DNA extraction was then performed using a Fast DNA SPIN Kit for Soil Kit (MP Biotechnology, USA) according to the manufacturer's protocol. The V4-V5 region of the bacterial 16S ribosomal RNA genes were amplified by PCR $\left(95^{\circ} \mathrm{C}\right.$ for $2 \mathrm{~min}$, followed by 25 cycles at $95^{\circ} \mathrm{C}$ for $30 \mathrm{~s}, 55^{\circ} \mathrm{C}$ for $30 \mathrm{~s}$, and $72^{\circ} \mathrm{C}$ for $30 \mathrm{~s}$, and a final extension at $72^{\circ} \mathrm{C}$ for $5 \mathrm{~min}$ ) using primers 515F 5'-barcode-GTGCCAGCMGCCGCGG)-3' and 907R 5'-CCGTCAATTCMTTTRAGTTT-3', where the barcode is an eight-base sequence unique to each sample [12]. PCR reactions were performed in triplicate $20 \mu \mathrm{L}$ reaction volumes containing $4 \mu \mathrm{L}$ of $5 \times$ FastPfu Buffer, $2 \mu \mathrm{L}$ of $2.5 \mathrm{mM}$ dNTPs, $0.8 \mu \mathrm{L}$ of each primer $(5 \mu \mathrm{M}), 0.4 \mu \mathrm{L}$ of FastPfu Polymerase, and 10ng of template DNA.

\section{Illumina MiSeq Sequencing}

Amplicons were extracted from $2 \%(\mathrm{w} / \mathrm{v})$ agarose gels and purified using the AxyPrep DNA Gel Extraction Kit (Axygen Biosciences, Union City, CA, USA) according to the manufacturer's instructions and quantified using QuantiFluor-ST (Promega, Madison, WI, USA). Purified amplicons were pooled in equimolar amounts and paired-end sequenced $(2 \times 250)$ on an Illumina MiSeq platform according to the standard protocols.

\section{Processing Sequencing Data}

Raw fastq files were demultiplexed and quality-filtered using QIIME (version 1.17) with the following criteria: (i) The 300-bp reads were truncated at any site receiving an average quality score of $<20$ over a $50 \mathrm{bp}$ sliding window, discarding the truncated reads that were shorter than $50 \mathrm{bp}$; (ii) exact barcode matching, two nucleotide mismatch in primer matching and reads containing ambiguous characters were removed; and (iii) only sequences with overlap longer than $10 \mathrm{bp}$ were assembled according to their overlap sequence. Reads which could not be assembled were discarded.

Operational Units (OTUs) were clustered with 97\% similarity cutoff using UPARSE (version 7.1 drive5. com/uparse) and chimeric sequences were identified and removed using UCHIME. The taxonomy of each 16S rRNA gene sequence was analyzed by RDP Classifier (rdp.cme.msu.edu) against the silva (SSU115)16S rRNA database using a confidence threshold of $70 \%[13]$. 


\section{Statistical Analysis}

The Shannon-Wiener index was used to assess bacterial diversity. Detrended correspondence analysis (DCA) was performed to examine the variation among bacterial communities of these six samples. These statistical analyses were performed using the VEGAN package in $\mathrm{R}$ (v.2.15.1, r-project.org).

\section{Results and Discussion}

\section{Efficiencies of the Combined A/O+BIOFOR Process on Pollutant Removal}

During the 181-day study period, the influent COD concentration ranged from 1,618-2,286 mg/L (Fig. 1). The effluent COD concentration remained relatively stable with an average of $52 \mathrm{mg} / \mathrm{L}$ (Fig. 1). In general, COD removal rate did not change significantly and saw minor fluctuations around $97.5 \%$. The influent $\mathrm{NH}_{4}^{-}-\mathrm{N}$ concentration fluctuated from 32 to $68 \mathrm{mg} / \mathrm{L}$ during the 181-day study period (Fig. 2). The effluent $\mathrm{NH}_{4}^{-}-\mathrm{N}$ concentration showed an increasing trend after 16 days of operation, reaching a maximum of $9.7 \mathrm{mg} / \mathrm{L}$. After day 16, the effluent $\mathrm{NH}_{4}^{-}-\mathrm{N}$ concentration was generally stable. The $\mathrm{NH}_{4}^{-}$Naverage removal rate was $84.51 \%$ (Fig. 2). During the first 100 days, the influent suspended solids (SS) concentration fluctuated from 36 to $88 \mathrm{mg} / \mathrm{L}$, with the lowest concentration of $36 \mathrm{mg} / \mathrm{L}$ on day 73 (Fig. 3). After day 100, the SS concentrations were relatively stable, ranging from 68 to $85 \mathrm{mg} / \mathrm{L}$. The effluent SS concentration fluctuated from 13 to $28 \mathrm{mg} / \mathrm{L}$ and the average SS removal rate was $69.07 \%$ (Fig. 3). All these results showed that the combined $\mathrm{A} / \mathrm{O}+\mathrm{BIOFOR}$ were effective in treating the mixed pharmaceutical wastewater; and the three indexes of the effluent met the Chinese discharge standard of water pollutants for the pharmaceutical industry mixing/compounding and formulation category in China (GB21908-2008).

\section{Bacterial Community Structures in the Combined A/O+BIOFOR Process}

There were 21,064-28,205 effective reads for the six activated sludge samples (Table 1). The average number of OTUs from A/O system was 1,129, significantly lower than the BIOFOR reactor $(1,350)(p<0.05)$. Similarly, the average Shannon-Wiener index in $\mathrm{A} / \mathrm{O}(5.02)$ was significantly lower than that in the BIOFOR reactor (5.83). These Shannon-Wiener values are typical for diverse microbial populations without a few strongly dominant $\operatorname{tax}[14]$.

Candidate-division_TM7 was the most predominant phyla in the A/O system, accounting for $31.72-33.81 \%$ of the total effective bacterial sequences, followed by Proteobacteria (19.46-23.76\%). However, in the BIOFOR reactor, the most dominant phylum was Proteobacteria, accounting for $36.35-46.68 \%$ of total effective bacterial sequences (Fig. 4). Similar results were obtained in previous studies, which found that Proteobacteria were the dominant members of wastewater microbial communities [15-19]. Previous studies also suggested that the most diverse group of bacteria in 6- and 12-dayold biofilms was Proteobacteria [20-21]. The Gramnegative Proteobacteria are a major group of bacteria

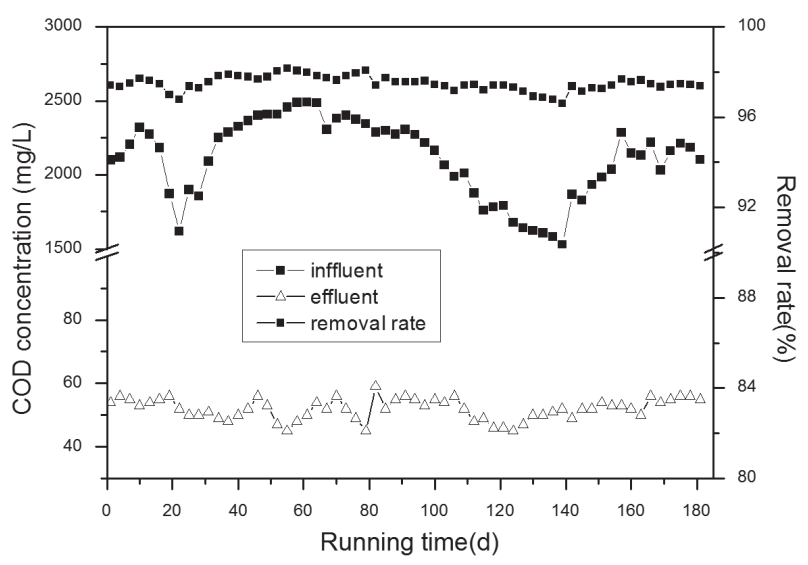

Fig. 1. COD removal by the combined $\mathrm{A} / \mathrm{O}+\mathrm{BIOFOR}$ process.

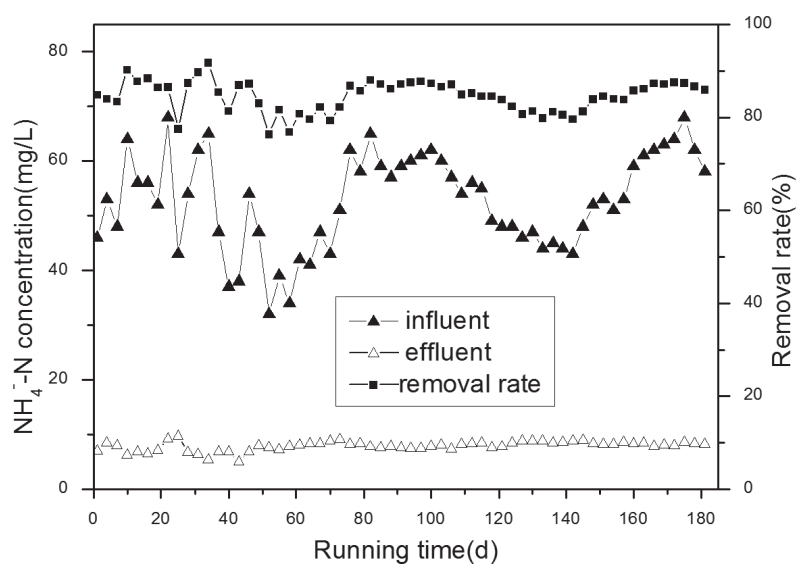

Fig. 2. $\mathrm{NH}_{4}^{-}-\mathrm{N}$ removal by the combined $\mathrm{A} / \mathrm{O}+\mathrm{BIOFOR}$ process.

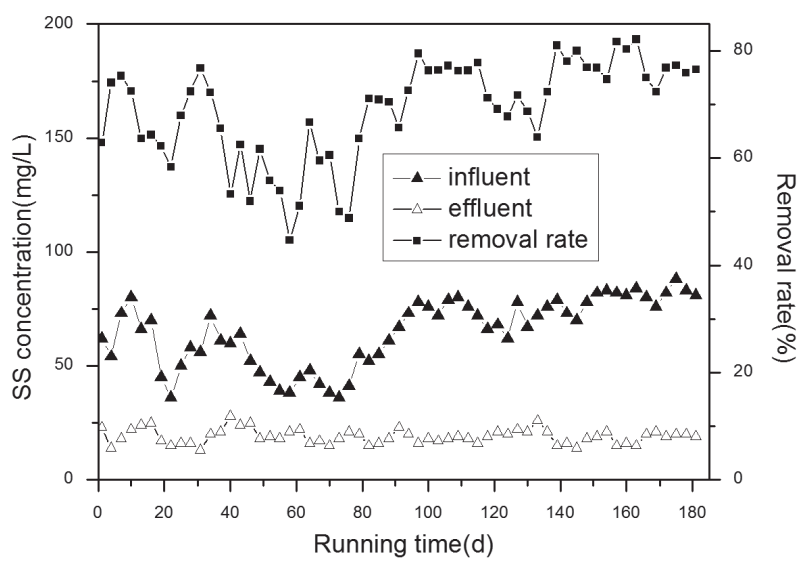

Fig. 3. SS removal by the combined $\mathrm{A} / \mathrm{O}+\mathrm{BIOFOR}$ BIOFOR process. 
Table 1. Diversity indices from six samples.

\begin{tabular}{|c|c|c|c|}
\hline Samples & Sequences & OTUs & Shannon-Wiener \\
\hline O1 & 21,064 & 1,073 & 4.96 \\
\hline O2 & 28,179 & 1,148 & 5.04 \\
\hline O3 & 27,350 & 1,167 & 5.07 \\
\hline B1 & 27,876 & 1,407 & 6.25 \\
\hline B2 & 27,257 & 1,254 & 5.96 \\
\hline B3 & 28,205 & 1,390 & 6.28 \\
\hline
\end{tabular}

encompassing a wide variety of aerobic, anaerobic, and facultative bacteria [22] that are able to degrade a broad spectrum of organic contaminants and enable biological nitrogen and phosphorus removal [23]. In the BIOFOR reactor, Firmicutes was also is the dominant phyla in the BIOFOR reactor (Fig. 4). This observation was consistent with Shi et al. [24], who reported that Firmicutes were the predominant group in the anaerobic process for pharmaceutical wastewater treatment. Chloroflexi and Acidobacteria were highly enriched in both reactors. In addition, the percentages of Actinobacteria and Bacteroideteswere were similar in the two systems (Fig. 4).

At the genus level, a total of 327 genera were acquired from all six samples. Among the 327 assigned genera, 201 were shared by both $\mathrm{A} / \mathrm{O}$ and $\mathrm{BIOFOR}$ reactors, such as

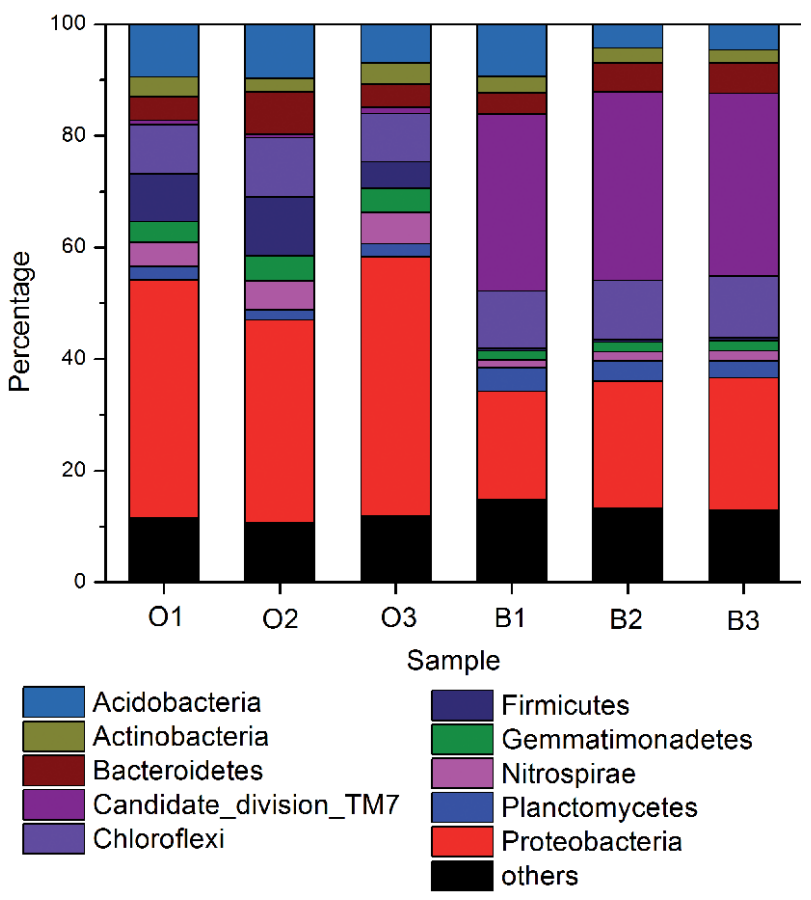

Fig. 4. Abundances of different phyla in the six activated sludge samples. The abundances are presented in terms of percentage of total effective bacterial sequences in a sample. O1, O2, and $\mathrm{O} 3$ indicate the three replicate samples from the aeration tank of the $\mathrm{A} / \mathrm{O}$ system, and $\mathrm{B} 1, \mathrm{~B} 2$, and $\mathrm{B} 3$ indicate the three replicate samples from the BIOFOR reactor.
Ferruginibacter and Zoogloea, and accounted for 71-89\% of the classified sequences. Members of Ferruginibacter, such as Ferruginibacter alkalilentus and Ferruginibacter lapsinanis, are capable of hydrolyzing some organic matter. Members of Zoogloea, such as Zoogloea ramigera, have long been considered the typical activated sludge bacteria responsible for the formation of activated sludge flocculation and to improve the purification process [25]. One-hundred and twenty-six genera were observed only in $\mathrm{A} / \mathrm{O}$ or BIOFOR reactors, and they accounted for $11-29 \%$ of total classified sequences in each sample. Although the two reactor share the majority of the genera, they also harbor some unique genera.

The 15 most abundant genera in each sample were selected (a total of 33 genera for all six samples), and their abundances were compared to those in other samples (Fig. 5). In the A/O system, Candidate_division_TM7_ norank was the most dominant, and Anaerolineaceae uncultured, Nitrosomonadaceae uncultured, Caldilineaceae_uncultured, and WCHB1-60_norank were also highly enriched. In the BIOFOR reactors, Pseudomonas had relatively high proportions, which have been identified as potential pathogens in a drinking water treatment membrane filtration system [26]. Geobacter was found to be dominant in BIOFOR samples, but it was found in limited amounts in A/O samples. Similarly,

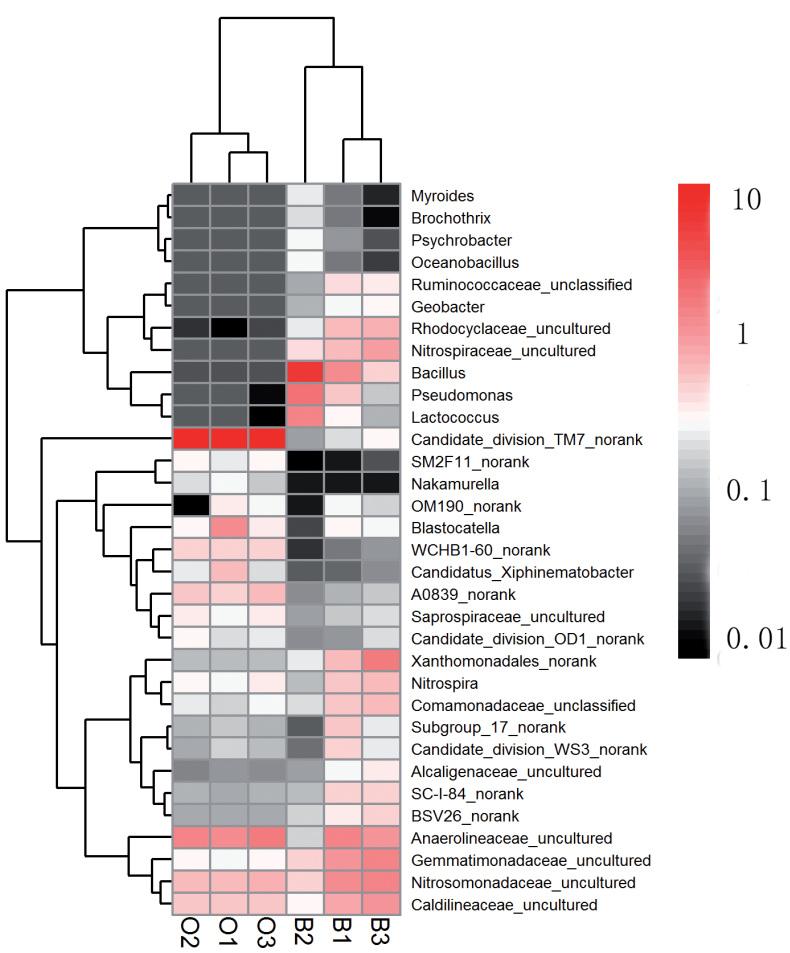

Fig. 5. Heat map of top 15 genera in each sample. Thirty-three genera were selected from six samples; the color intensity in each panel shows the percentage of that genus in the sample in reference to the color key on the right-hand side. O1, O2, and $\mathrm{O} 3$ indicate the three replicate samples from the aeration tank of the $\mathrm{A} / \mathrm{O}$ system, and $\mathrm{B} 1, \mathrm{~B} 2$, and $\mathrm{B} 3$ indicate the three replicate samples from the BIOFOR reactor. 


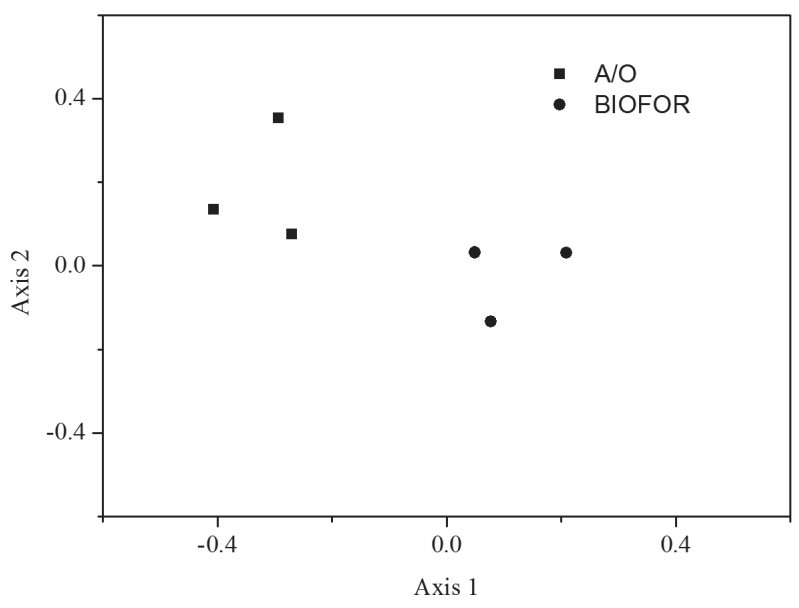

Fig. 6. DCA of bacterial communities from $\mathrm{A} / \mathrm{O}$ and BIOFOR systems.

the percentage of Bacillus in the BIOFOR reactor was higher than that in the $\mathrm{A} / \mathrm{O}$ system. While the percentage of Anaerolineaceae_uncultured in the BIOFOR reactor was lower than in $\mathrm{A} / \mathrm{O}$ samples. The proportions of Anaerolineaceae uncultured, Nitrosomonadaceae uncultured, and Cakdilineaceae uncultured in the two reactors were not significantly different.

All these results suggested that the two systems harbor different bacterial communities. The DCA results also showed that the samples from $\mathrm{A} / \mathrm{O}$ and BIOFOR were distributed in different parts of the data space (Fig. 6).

\section{Conclusions}

The $\mathrm{A} / \mathrm{O}+\mathrm{BIOFOR}$ combined processes were suitable for the treatment of mixed pharmaceutical wastewater. The effluent water met the Chinese mission standard of water pollutants for the pharmaceutical industry mixing/compounding and formulation category (GB21908-2008). MiSeq sequencing data showed that the two systems (A/O and BIOFOR) harbored different bacterial communities and diversity. The result also revealed that dominated bacterial communities make great contributions to pollutant removal. The results of this study provided insights into the bacterial community structure and diversity in a pharmaceutical wastewater treatment system and can provide reference for the treatment of mixed pharmaceutical wastewater.

\section{Acknowledgements}

This work was supported by the NSFC (51408020) and Implement Project of Science and Technology of Colleges and Universities in Jiangxi Province (KJLD13007).

\section{References}

1. NG K.K., SHIX., NG H.Y.Evaluation of System Performance and Microbial Communities of a Bioaugmented Anaerobic Membrane Bioreactor Treating Pharmaceutical Wastewater. Water Research 81, 311, 2015.

2. SHI X., LEFEBVRE O., NG K.K.,NG H.Y. Sequential anaerobic-aerobic treatment of pharmaceutical wastewater with high salinity. Bioresource Technology 153C, 79, 2013.

3. LI W., NIU Q., HONG Z., ZHE T., YU Z., GAO Y., LI Y.Y., NISHIMURA O., YANG M. UASB treatment of chemical synthesis-based pharmaceutical wastewater containing rich organic sulfur compounds and sulfate and associated microbial characteristics. Chemical Engineering Journal 260, 55, 2015.

4. GAO D., ZHE L., GUAN J., LI Y., REN N. Removal of surfactants nonylphenol ethoxylates from municipal sewagecomparison of an $\mathrm{A} / \mathrm{O}$ process and biological aerated filters. Chemosphere 97, 130, 2013.

5. FARABEGOLI G., CHIAVOLA A., ROLlE E. The Biological Aerated Filter (BAF) as alternative treatment for domestic sewage. Optimization of plant performance. Journal Of Hazardous Materials 171, 1126, 2009.

6. WANG B., PENG Y., GUO Y., ZHAO M., WANG S. Illumina MiSeq sequencing reveals the key microorganisms involved in partial nitritation followed by simultaneous sludge fermentation, denitrification and anammox process. Bioresource Technology 207, 118, 2016.

7. WANG X., XIA Y., WEN X., YANG Y., ZHOU J. Microbial Community Functional Structures in Wastewater Treatment Plants as Characterized by GeoChip. Plos One $\mathbf{9}$, 2014.

8. SCHUPPLER M., MERTENS F., SCHÖN G., GÖBEL U.B. Molecular characterization of nocardioform actinomycetes in activated sludge by $16 \mathrm{~S}$ rRNA analysis. Microbiology 141 ( Pt 2), 513, 1995

9. YANG K., YUE Q., KONG J., ZHAO P., GAO Y., FU $\mathrm{K}$., GAO B. Microbial diversity in combined UAF-UBAF system with novel sludge and coal cinder ceramic fillers for tetracycline wastewater treatment. Chemical Engineering Journal 285, 319, 2016.

10. ZHOU J., ZHOU X., LI Y., XING J. Bacterial communities in haloalkaliphilic sulfate-reducing bioreactors under different electron donors revealed by $16 \mathrm{~S}$ rRNA MiSeq sequencing. Journal Of Hazardous Materials 295, 176, 2015.

11. WANG X., WEN X., XIA Y., HU M., ZHAO F., DING K. Ammonia oxidizing bacteria community dynamics in a pilotscale wastewater treatment plant. Plos One 7, e36272, 2012.

12. WANG X.H., WEN X.H., YAN H.J., DING K., ZHAO F., HU M. Bacterial community dynamics in a functionally stable pilot-scale wastewater treatment plant. Bioresource Technology 102, 2352, 2011.

13. AMATO K.R., YEOMAN C.J., KENT A., RIGHINI N., CARBONERO F., ESTRADA A., GASKINS R., STUMPF R.M., YILDIRIM S., TORRALBA M., GILLIS M., WILSON B.A., NELSON K.E., WHITE B.A., LEIGH S. Habitat degradation impacts black howler monkey (Alouatta pigra) gastrointestinal microbiomes. Isme Journal 7, 1344, 2013.

14. XIA S., DUAN L., SONG Y., LI J., PICENO Y.M., ANDERSEN G.L., ALVAREZ-COHEN L., MORENOANDRADE I., HUANG C., HERMANOWICZ S.W. Bacterial community structure in geographically distributed 
biological wastewater treatment reactors. Environmental Science \& Technology 44, 7391, 2010.

15. KWON S., KIM T.S., YU G.H., JUNG J.H., PARK H.D. Bacterial community composition and diversity of a fullscale integrated fixed-film activated sludge system as investigated by pyrosequencing. Journal of Microbiology \& Biotechnology 20, 1717, 2010.

16. WANG Y., SHENG H.F., HE Y., WU J.Y., JIANG Y.X., TAM N.F.Y., ZHOU H.W. Comparison of the levels of bacterial diversity in freshwater, intertidal wetland, and marine sediments by using millions of illumina tags. Applied \& Environmental Microbiology 78, 8264, 2012.

17. COLLADO N., BUTTIGLIERI G., MARTI E., FERRANDO-CLIMENT L., RODRIGUEZ-MOZAZ S., BARCELÓ D., COMAS J., RODRÍGUEZ-RODA I. Effects on activated sludge bacterial community exposed to sulfamethoxazole. Chemosphere 93, 99, 2013.

18. ROESCH L., FULTHORPE R.R., RIVA A., CASELLA G., HADWIN A.K., KENT A.D., DAROUB S.H., CAMARGO F.A.O., FARMERIE W., TRIPLETT E. Pyrosequencing enumerates and contrasts soil microbial diversity. Isme Journal 1, 283, 2007.

19. LI B., ZHANG X., GUO F., WU W., ZHANG T. Characterization of tetracycline resistant bacterial community in saline activated sludge using batch stress incubation with high-throughput sequencing analysis. Water Research 47, 4207, 2013.

20. CHUNG H.C., LEE O.O., HUANG Y.L., MOK S.Y., KOLTER R., QIAN P.Y. Bacterial community succession and chemical profiles of subtidal biofilms in relation to larval settlement of the polychaete Hydroides elegans. Isme Journal 4, 817, 2010.

21. LEE O.O., WANG Y., YANG J., LAFI F.F., ALSUWAILEM A., QIAN P.Y. Pyrosequencing reveals highly diverse and species-specific microbial communities in sponges from the Red Sea. Isme Journal 5, 650, 2011.

22. QI Y., XIONG P., DING P., CHU L., WANG J. Treatment of petrochemical wastewater by microaerobic hydrolysis and anoxic/oxic processes and analysis of bacterial diversity. Bioresource Technology 196, 169, 2015.

23. SNAIDR J., AMANN R., HUBER I., LUDWIG W., SCHLEIFER K.H. Phylogenetic analysis and in situ identification of bacteria in activated sludge. Applied \& Environmental Microbiology 63, 2884, 1997.

24. SHI X., NG K.K., LI X.R., NG H.Y. Investigation of Intertidal Wetland Sediment as a Novel Inoculation Source for Anaerobic Saline Wastewater Treatment. Environmental Science \& Technology 49, 6231, 2015.

25. WANG X., HU M., XIA Y., WEN X., DING K. Pyrosequencing analysis of bacterial diversity in 14 wastewater treatment systems in china. Applied And Environmental Microbiology 78, 7042, 2012.

26. KWON S., MOON E., KIM T.S., HONG S., PARK H.D. Pyrosequencing demonstrated complex microbial communities in a membrane filtration system for a drinking water treatment plant. Microbes \& Environments 26, 149, 2011. 